\title{
Hubungan Orientasi Karier dengan Optimisme pada Mahasiswa Jurusan Keagamaan UIN Sunan Gunung Djati Bandung
}

Tasya Augustiya $^{1}$, Qori Nurislamiaty ${ }^{2}$, Muhammad Dasrais Al-fatoni ${ }^{3}$, Lea Nurbayu Rachma ${ }^{4}$

${ }_{1,2,3,4}$ UIN Sunan Gunung Djati, J1. A. H. Nasution No.105 Cibiru - Bandung

${ }^{1} e$-mail: tasyaaugustiyaxia1@gmail.com

\begin{tabular}{|c|c|}
\hline Abstract / Abstrak & Keywords / Kata kunci \\
\hline $\begin{array}{l}\text { The community's stigma regarding the low employment prospects of religious } \\
\text { majors did not lower their optimism. They still feel optimistic because they } \\
\text { already had an overview of their careers (career orientation). The study aims to } \\
\text { examine the relationship between career orientation and optimism in students } \\
\text { majoring in religion and how much the relationship between the two. This study } \\
\text { used } 2 \text { instruments, namely the LOT-R scale to measure optimism and Career } \\
\text { Maturity Inventory (CMI) to measure career orientation. Both of these scales are } \\
\text { scales that have been adapted in Indonesia by previous researchers and have } \\
\text { been modified by the researchers. The sample in this study was } 98 \text { students } \\
\text { majoring in religion, which was collected by purposive sampling technique. The } \\
\text { results of the study indicate that there is a relationship between career orientation } \\
\text { and optimism. }\end{array}$ & $\begin{array}{l}\text { Career Orientation } \\
\text { Optimism } \\
\text { Religious Department } \\
\text { Students }\end{array}$ \\
\hline $\begin{array}{l}\text { Stigma masyarakat terhadap rendahnya prospek kerja bagi mereka yang } \\
\text { lulusan jurusan keagamaan tidak serta-merta membuat optimisme mereka } \\
\text { berkurang. Sebaliknya mereka cenderung lebih optimis karena } \\
\text { mempunyai orientasi karier yang jelas. Studi ini menguji hubungan } \\
\text { orientasi karier dengan optimisme. Dua skala yang digunakan adalah } \\
\text { LoT-R yang mengukur optimisme dan Career Maturity Inventory yang } \\
\text { mengukur orientasi karier. Kedua skala sudah diadaptasi dan kemudian } \\
\text { dilanjutkan modifikasi oleh peneliti. sampel terdiri dari } 98 \text { responden } \\
\text { yang dipilih dengan teknik purposive sampling. Hasil menunjukkan } \\
\text { bahwa terdapat hubungan yang moderat antara orientasi karier dengan } \\
\text { optimisme. }\end{array}$ & $\begin{array}{l}\text { Orientasi Karir } \\
\text { Optimisme } \\
\text { Mahasiswa Jurusan } \\
\text { Keagamaan }\end{array}$ \\
\hline
\end{tabular}

\section{Pendahuluan}

UIN Sunan Gunung Djati Bandung adalah salah satu Perguruan Tinggi Negeri Islam pertama di Jawa Barat. Sebelumnya, UIN Sunan Gunung Djati Bandung ini berdiri sebagai Institut Agama Islam Negeri yang hanya fokus pada jurusan-jurusan keagamaan Islam. Namun, seiring dengan pesatnya perkembangan ilmu pengetahuan dan teknologi, UIN SGD Bandung pun akhirnya diresmikan dengan membuka jurusan-jurusan sains dan umum (UIN Sunan Gunung Djati Bandung, 2019).

Semakin hari, keberadaan jurusan-jurusan umum menjadi lebih unggul dan banyak diminati dibanding dengan jurusan keagamaan, padahal jurusan keagamaan merupakan embrio dari UIN SGD Bandung karena jurusan-jurusan tersebut sudah ada jauh sebelum UIN SGD Bandung diresmikan (Emiriza, 2019). Sementara itu, alumni Fakultas Ushuluddin ada yang bekerja sebagai Wartawan, Peneliti LSM, Da'i, Guru, Dosen bahkan Politisi Nasional. Contoh konkretnya yaitu, Burhanuddin Muhtadi dan Saiful Mujani yang saat ini bekerja sebagai peneliti disebuah lembaga survei terkemuka; Zainuddin MZ sebagai da'i sejuta umat Komaruddin Hidayat rektor UIN Jakarta; Ade Komaruddin Anggota Dewan Perwakilan Rakyat (DPR) dari Partai Golkar, dan masih banyak lagi yang menjadi tokoh yang dikenal banyak orang (UIN Sunan Gunung Djati Bandung, 2019). 
Berdasarkan data jumlah peminat setiap jurusan di UIN Bandung pada tahun 2016-2018, didapat lima prodi dengan peminat terendah yaitu Perbandingan Mazhab dan Hukum, Perbandingan Agama (berubah nama menjadi Studi Agama-Agama), Filsafat Agama, Ilmu Hadist dan Ilmu Al'quran dan Hadist atau Ilmu Quran Tafsir (UIN Sunan Gunung Djati Bandung, 2019).

Rendahnya peminat pada jurusan-jurusan tersebut disebabkan oleh banyaknya masyarakat awam yang beranggapan bahwa prospek kerja jurusan keagamaan tidak seluas jurusan-jurusan umum (Syaddad, 2016). Padahal jika dicermati dengan benar, semua jurusan pun memiliki peluang atau prospek dibidangnya masingmasing. Misalnya, jurusan Al-Quran dan Tafsir peluang kerjanya dapat menjadi konsultan atau penyuluh agama dan pegawai kantor Kementerian Agama pusat, wilayah, kabupaten maupun kota. Lulusan Jurusan/Program Studi Ilmu Al-Qur'an dan Tafsir juga dapat menjadi pengajar di Pesantren (IAIN Pekalongan, 2014).

Melihat fenomena tentang stigma masyarakat yang tidak menaruh keyakinan untuk masuk di jurusan keagamaan tersebut,tentunya akan berdampak pada rasa keyakinan diri atau optimisme pada mahasiswa yang saat ini sedang menempuh pendidikan di jurusan tersebut. Sementara itu, dukungan sosial sangat berpengaruh terhadap tingkat optimisme pada seseorang, sehingga besar kemungkinan jika mahasiswa tidak mendapat dukungan sosial seperti itu, rasa optimisme pada diri mereka saat berkuliah dan merancang masa depan menjadi rendah (Ushfuriyah., 2000).

Optimisme adalah pengharapan yang cenderung stabil pada diri individu dalam memrediksi masa depan yang diperkirakan akan diperoleh hal-hal yang lebih baik (Scheier \& Carver, 1985). Tingkat optimisme pada diri individu dipengaruhi oleh banyak faktor, diantaranya faktor pengalaman, genetis, status sosial ekonomi, ras atau budaya, dan sumber daya sosial (Riziq, 2015).
Hanssen et al. (2015) juga menyampaikan ide atau pendapat yang menyatakan bahwa ketika kita hedak membuat ketahanan karir pada diri individu berkembang bisa diperoleh dari optimisme individu yang menjadi bagian atau konstruk dalam psikologis, hal ini dikarenakan individu yang optimis lebih mempunyai kemampuan untuk bertahan ketika dihadapkan pada kesulitan awal (Rasmussen, Wrosch, Michael, \& Carver, 2006) serta individu yang optimisnya tinggi memiliki tingkat distres pikologis yang rendah. Selain itu, penelitian lainnya juga mengungkapkan dalam konteks akademik kecenderungan orang untuk optimisme itu lebih besar terlebih jika secara pribadi individu mempunyai kualitas diri yang baik dan mempunyai integritas akademik yang sesuai. Hal ini kemudian mengasumsikan bahwa optimisme berkorelasi positif dan signifikan dengan integritas akademik (Ramdani, 2018).

Orang yang memiliki sikap optimis adalah individu yang tidak pernah memandang kendala atau hambatan sebagai akhir dari segalanya, tapi individu tersebut akan terus berjuang mencari titik terang dan jalan keluar dari masalahnya tersebut. Individu akan lebih sehat jika memiliki sifat optimisme yang tinggi karena memiliki keinginan untuk menjadi orang yang bisa menghasilkan sesuatu, dan juga memiliki harapan yang positif. Selain itu individu yang memiliki optimisme yang besar biasanya lebih cerdas secara emosi, seperti tidak mudah putus asa, tidak merasa bodoh dan tidak rentan depresi, sehingga disaat mengalami kegagalan, ia akan melakukan respon positif dan lebih memilih untuk mencari jalan keluar (Prasetyo \& Prasojo, 2016). Ciriciri individu yang memiliki optimisme tinggi adalah individu yang tidak terindikasi depresi sehingga ia akan lebih mudah menggapai kesuksesan dalam hidupnya, memiliki kepercayaan, dapat berubah ke arah yang lebih baik, serta adanya pemikiran dan kepercayaan berkenaan dengan usahanya untuk menggapai sesuatu yang lebih, dan terus berusaha dengan kesadaran penuh 
(Noordjanah, 2002). Sikap optimisme yang dimiliki oleh setiap individu diciptakan oleh karakter kepribadiannya. Mereka yang cenderung optimis akan lebih percaya diri, nyaman, ekspresif dan selalu beranggapan positif terhadap semua yang terjadi.

Namun, terlepas dari itu, berdasarkan data yang didapat dari 10 orang mahasiswa jurusan keagamaan di UIN SGD Bandung, mereka menyatakan tetap optimis karena mereka sudah memiliki gambaran apa saja yang akan mereka lakukan setelah lulus, sudah merencanakan akan bekerja dimana serta jabatan yang akan ia capai jika menempuh pendidikan jurusan keagamaan. Seperti halnya mahasiswa Jurusan Pengembangan Masyarakat Islam, mereka memiliki pemikiran yang luas terhadap masa depan dan karir mereka setelah lulus. Ketika ditanya rencana mereka akan bekerja dimana, mereka sangat percaya diri akan bekerja di Kementerian Agama, atau bahkan banyak dari mereka yang memiliki orientasi karirnya terjun ke sosial masyarakat langsung yaitu kembali ke Desa dan mengembangkan sumber daya masyarakat Desa yang berlandaskan Islami.

Oleh karena itu, ketika diberikan rentang angka 1-10 untuk menentukan besarnya optimisme mereka, mahasiswa jurusan Pengembangan Masyarakat Islam tersebut ratarata memilih diangka 10 yang artinya mereka mengaku memiliki tingkat optimisme yang maksimal. Dari data tersebut, didapat bahwa dalam permasalahan mengenai besar tidaknya peluang kerja tersebut sebenarnya tergantung pada orientasi karir dari mahasiswa itu sendiri.

Menurut Super (dalam Sharf, 1992) kesiapan individu untuk membuat keputusan karir yang tepat terakumulasi pada orientasi karir secara total. Orientasi karir ini terdiri atas tiga dimensi, yaitu: sikap terhadap karir (career development attitudes), keterampilan pembuatan keputusan karir (skills of carrer development decision making), dan informasi dunia kerja (world-of-work information). Dari hasil data awal kami, mahasiswa sudah memiliki informasi dunia kerja karena dapat menentukan akan jadi apa dan bekerja dimana, hal itulah yang jelas akan menjadi alasan kita untuk selalu optimis kuliah di jurusan keagamaan maupun jurusan lainnya. Pada dasarnya setiap orang memiliki orientasi karirnya masing-masing dan berbeda satu sama lain.

Menurut Osipow (1983) orientasi karir adalah orientasi atau cara berpikir individu tentang gambaran yang dibuat untuk mendorong mereka melakukan pemilihan karir atau pekerjaan. Salah satu faktor orientasi diri yaitu konsep diri sebagai salah satu unsur dalam faktor kepribadian yang disampaikan oleh Super (Osipow, 1983). Kurniawan, Priyatama, \& Karyanta (2007) menyebutkan konsep diri mempunyai hubungan yang signifikan terhadap optimisme. Hal inilah yang menjadikan indikasi bahwa akan ada pula hubungan antara optimisme dengan orientasi karir tersebut.

Untuk lebih lengkapnya, Super juga mengelompokkan beberapa faktor lain yang dapat berpengaruh terhadap orientasi karir ke dalam lima kategori (Osipow, 1983). Diantanya sebagai berikut:

1. Faktor bio-sosial. Faktor ini maksudnya berupa informasi khusus, perancangan, tanggung jawab, penerimaan dalam memikirkan rencana karir. Yang termasuk kedalam faktor bio-sosial ini salah satunya adalah usia.

2. Faktor lingkungan. Faktor ini memuat tentang indeks kematangan karir yang berkaitan dengan pekerjaan orang tua, kurikulum sekolah, pengaruh budaya dan keluarga.

3. Faktor Kepribadian. Faktor tersebut memuat tentang konsep diri dan fokus pada kendali, bakat khusus, norma, dan tujuan hidup seseorang. Seperti pada penjelasan sebelumnya mengenai konsep diri, terbukti pada hasil penelitian Kurniawan, Priyatama, \& Karyanta (2007) konsep diri mempunyai hubungan yang signifikan terhadap optimisme.

4. Faktor vokasional. Faktor ini berkaitan dengan kematangan karir seseorang yang memiliki hubungan positif dengan aspirasi 
vokasional, keselarasan aspirasi dan harapan karir.

5. Faktor Prestasi individu. Faktor tersebut diantaranya prestasi akademik individu, kebebasan, partisipasi di dalam maupun luar sekolah.

Pentingnya orientasi karir dalam kaitannya dengan optimisme berdasarkan penjelasanpenjelasan diatas dan beragam penelitian sebelumnya, menarik perhatian peneliti untuk melakukan penelitian mengenai hubungan orientasi karir dengan optimisme pada mahasiswa jurusan keagamaan.

\section{Metode}

\section{Desain Penelitian}

Metode yang digunakan dalam penelitian ini adalah metode penelitian kuantitatif. Metode penelitian kuantitatif adalah menggunakan data yang berupa angka dimana angka tersebut merupakan hasil dari olahan menggunakan program statistika untuk menjawab permasalahan dalam suatu penelitian (Fleeson et al., 2017). Pada penelitian yang kami lakukan ini, analisis penelitian yang digunakan adalah jenis penelitian korelasional dimana jenis tersebut memiliki tujuan untuk mempelajari informasi dan berusaha membuktikan bahwa pada dua skala konstruk yang diukur mempunyai taraf hubungan (Azwar, 2007). Dalam hal ini bertujuan untuk menentukan hubungan antara orientasi karir dengan optimisme mahasiswa jurusan keagamaan di UIN SGD Bandung.

\section{Populasi dan Sampel}

Sampel dalam penelitian ini berjumlah 100 responden dimana subjek tersebut merupakan mahasiswa jurusan keagamaan Universitas Islam Negeri Sunan Gunung Djati Bandung dengan menggunakan teknik pengambilan data purposive sampling. Teknik ini merupakan salah satu teknik pengambilan data yang sangat sering untuk digunakan dalam penelitian kuantitatif. Metode ini menggunakan kriteria yang sebelumnya telah dipilih oleh peneliti, dalam memilih sampel kriteria pemilihan sampel terbagi menjadi kriteria inklusi dan ekslusi.

Dalam hal ini yang menjadi kriteria inklusi adalah mahasiswa juruan keagamaan Universitas Islam Negeri Sunan Gunung Djati Bandung yang duduk di semester 1 sampai semester 7. Adapun kriteria ekslusinya adalah mereka yang berada di jurusan-jurusan keagamaan di Uniersitas Islam Negeri Sunan Gunung Djati tersebut diantaranya jurusanjurusan yang ada di Fakultas Ushuluddin seperti Perbandingan Mazhab dan Hukum, Perbandingan Agama (berubah nama menjadi Studi Agama-Agama), Filsafat Agama, Ilmu Hadist dan Ilmu Al'quran dan Hadist (Ilmu Quran Tafsir), Tasawuf dan Psikoterapi, selain itu jurusan di Fakultas lainnya seperti jurusan Sejarah Peradaban Islam, Pengembangan Masyarakat Islam, Perbandingan Madzhab, Hukum Keluarga Islam, dan lain sebagainya.

\section{Intrumen Alat Ukur \\ Skala orientasi karir}

Skala orientasi karir ini mengacu pada skala kemantapan karir dalam career maturity inventory (CMI) merupakan sikap kematangan karir, skala sikap diarahkan untuk mengukur kecenderungan proses pemilihan karir (Sharf, 1992). Indikator-indikator yang diungkapkan dalam skala tersebut meliputi:

Tabel 1

Indikator Orientasi Karir

\begin{tabular}{cl}
\hline No. & \multicolumn{1}{c}{ Indikator } \\
\hline 1. & Keterlibatan (Involvement) \\
2. & Kemandirian (Independence) \\
3. & Pengenalan (Orientation) \\
4. & Penentuan (Decisiveness) \\
5. & Kompromi (Compromise) \\
\hline
\end{tabular}

Skala Orientasi karir telah diadaptasi oleh peneliti sebelumnya yang selanjutnya peneliti modifikasi dengan mengurangi item yang dianggap buruk jika dipakai pada penelitian ini. Adapun cara mengurangi item tersebut adalah dengan menggunakan uji daya beda. Yang 
mana di skala orientasi karir ini terdapat 90 item yang telah di ujikan kepada 30 responden sebagai data awal untuk uji alat ukur. Dari hasil tersebut didapat 54 aitem yang belum memenuhi syarat validitas menurut Azwar yaitu nilai dari hasil koefisien pada kolom signifikansi harus kurang dari 0,03 atau <0,03.

Sementara hasil uji reliabilitasnya $0,754>$ 0,7, menurut Azwar (2015) mengemukakan bahwa nilai koefisien pada kolom Cronbach's Alpha harus memiliki hasil lebih besar dari 0,7 atau $>0,7$ sehingga dapat dikatakan skala ini reliabel.

\section{Skala Optimisme}

Peneliti telah menyusun skala optimisme yang bertujuan untuk mengetahui sejauh mana optimisme pada jurusan keagamaan di UIN SGD Bandung. Skala yang digunakan adalah skala optimisme teori Scheier \& Carver (1985) dengan aspek positif dan negatif. Pada mulanya, Skala ini terdiri dari 8 item yang terdiri dari 2 aspek yang menyusun optimisme dan terdapat 4 item lainnya sebagai aitem pengalih perhatian dikarenakan sebelumnya mereka hanya menggunakan skala tersebut untuk mengukur keyakinan umum, sehingga dulunya skala ini disebut sebagai skala Life Orientation Test (LOT). Scheier dan Carver (1985) menjelaskan bahwa indikator dalam alat ukur ini mendeskripsikan hasil berdasarkan baik dan buruk dimana dalam hal ini diungkapkan dalam kalimat positif dan negatif pada redaksional skala.

Namun dalam perkembangannya, skala LOT tersebut direvisi oleh Scheier, Carver, \& Bridges (1994) dengan menghilangkan beberapa item yang dirasa terjadi tumpang tindih dengan coping. Revisi dilakukan dengan menghapus dua item yang berkaitan dengan coping, kedua item tersebut adalah item positif. Agar item positif dan negatif jumlahnya seimbang, satu item negatif juga dihapus dan dilakukan penambahan satu item positif. Setelah proses revisi selesai, skala Life Orientation Test (LOT) mengalami pergantian penyebutan dengan Life Orientation Test-
Revised (LOT-R) untuk menandakan skala tersebut telah direvisi.

Akhirnya, skala LOT-R ini berjumlah 10 aitem dengan 3 aitem positif (favorable), 3 item negatif (unfavorable), dan 4 item 32 pengalih (Scheier et al., 1994). Pertanyaan favorabel itu sendiri adalah pertanyaan yang mendukung objek yang diukur, sedangkan pertanyaan unfavorabel adalah pertanyaan yang tidak mendukung objek yang diukur.

Skala LOT-R yang kami gunakan ini telah diadaptasi ke dalam bahasa dan budaya Indonesia oleh peneliti sebelumnya dalam penelitian Riziq (2015) yang kemudian dimodifikasi oleh peneliti dengan menghapus item yang dinyatakan buruk pada uji daya beda dimana item tersebut telah kami ujikan pada 30 sampel responden. Yang hasilnya telah kami uji validitas. Dari hasil tersebut mengindikasikan bahwa terdapat 6 aitem dari 18 aitem yang belum memenuhi syarat validitas atau lebih besar dari 0,05 atau >0,05 yaitu seperti yang telah di jelaskan pada skala orientas karir, nilai dari hasil koefisien pada kolom signifikansi harus kurang dari 0,03 atau $<0,03$.

Hasil uji reliabilitasnya memiliki hasil 0,682 yang mengindikasikan bahwa hasilnya berada pada posisi kurang dari 0,7 atau < 0,7 yang pada dasarnya menurut Azwar, 1999 yang mengemukakan bahwa nilai koefisien pada kolom Cronbach's Alpha harus memiliki hasil lebih besar dari 0,7 atau > 0,7 agar variabelnya dapat dikatakan reliabel. Hal ini mengartikan bahwa hasil uji reliabilitas pada skala orientasi karir ini mengindikasikan variabel pada skala orientasi karir belum dapat dikatakan reliabel.

\section{Analisis Data \\ Uji Normalitas data}

Uji normalitas adalah salah satu uji yang digunakan sebagai cara untuk mengetahui dan menentukan teknik statistik apa yang akan digunakan untuk mengolah data selanjutnya. Data berdistribusi normal sehingga digunakan statistik parametrik. Rumus yang digunakan untuk pengujian normalitas distribusi data 
adalah Chi Kuadrat atau $\mathrm{x}^{2}$ (Wibowo, 2013). Pada penelitian kali ini peneliti akan melakukan uji normalitas menggunakan SPSS dengan cara uji One-Sample Kolmogorov-Smirnov test.

\section{Reliabilitas}

Dalam penelitian reliabilitas merupakan salah-satu ciri atau karakter utama instrumen pengukuran yang baik. Dalam penelitian reliabilitas merupakan salah-satu ciri atau karakter utama instrumen pengukuran yang baik (Azwar, 2003). Alat ukur dikatakan reliabilitas apabila memiliki kekonsistenan, artinya hasil akhirnya akan selalu sama walaupun tes tersebut diberikan pada kelompok yang sama pada waktu yang berbeda. Konsep reliabilitas dalam arti reliabilitas alat ukur sangat berkaitan dengan masalah kekeliruan pengukuran. Yang dimaksud dengan kekeliruan pengukuran apabila terjadi inkonsistensi hasil pengukuran terhadap pengukuran ulang pada kelompok atau subjek yang sama, maka kekeliruan pengukuran ini akan menunjukan sejauh mana inkonsistensi tersebut terjadi.

\section{Daya Beda}

Daya pembeda merupakan kemampuan soal untuk membedakan karakteristik antara orang yang mampu mengerjakan (kemampuan tinggi) dengan orang yang tidak mampu mengerjakan soal (kemampuan rendah). Besaran daya beda ditunjukan dengan indeks diskriminasi (D), indeks diskriminasi tersebut berkisan antara 0,00 sampai 1,00. Berbeda dengan indeks kesukaran yang tidak mengenal tanda (-), pada indeks diskriminasi terdapat tanda (-). Karena terdapat tanda (-) pada indeks diskriminasi nilainya berkisan antara $(-1,0)$ sampai $(0.00)$ dan $(0,00)$ sampai $(1,00)$ artinya (semakin ke kanan soal semakin baik, semakin ke kiri maka soal semakin jelek, sebab semakin ke kanan siswa yang pandai semakin sulit/tidak bisa menjawab dan sebaliknya siswa yang kurang pintar (kiri) bisa menjawab dengan asalasalan) (Solichin, 2017).

Menurut pendapat Karjono Natar daya beda memiliki fungsi sebagai berikut: untuk meningkatkan mutu setiap butir soal melalui data empiriknya. Serta untuk mengetahui seberapa jauh setiap butir soal dapat membedakan karakteristik orang yang mampu dan orang yang tidak mampu. Artinya bola butir soal tidak dapat membedakanya berarti ada kesalahan pada soal tersebut, seperti: (a) kesalahan kunci jawaban; (b) butir soal mempunyai dua jawaban yang benar; (c) tidak jelasnya ukuran kompetisi; (d) pengecoh tidak berfungsi; (e) materi yang ditanyakan terlalu sulit, sehingga banyak siswa yang menebak; (f) sebagian besar siswa yang memahami materi yang ditanyakan berpikir ada yang salah informasi dalam butir soalnya (Purwanto, 2011).

\section{Analisis Korelasi}

Metode yang digunakan dalam analisa data untuk penelitian ini adalah koefisien korelasi Pearson. Dalam hal ini koefisien korelasi (r) digunakan sebagaimana untuk mengetahui kuat atau tidaknya hubungan korelasi antar variablevariabel bebas dan variable tidak bebas (Budiwati et al., 2010). Nilai koefisien korelasi berada diantara 1 dan $-1(-1 \leq \mathrm{r} \leq 1)$. Variabel tersebut dikatakan memiliki korelasi yang kuat jika nilai koefisien korelasi nya lebih besar dari $(0,5)$ atau lebih kecil dari $(-0,5)$. Dalam hal ini jika ke jika nilai koefisien korelasinya positif (+) berarti mengindikasikan bahwa kenaikan (penurunan) nilai variabel bebas akan diikuti oleh kenaikan (penurunan) nilai variabel tidak bebas. Dan apabila jika nilai koefisien korelasinya negatif (-) berarti mengindikasikan bahwa kenaikan (penurunan) nilai variabel bebas pada umumnya diikuti oleh penurunan (kenaikan) nilai variabel tidak bebas.

\section{Hasil}

\section{Uji Daya Beda}

Tabel 2

Uji daya beda Orientasi Karir

\begin{tabular}{cccccccc}
\hline \multicolumn{7}{c}{ Nilai Uji Daya Beda Aitem Orientasi Karir } \\
\hline Item & D & Item & D & Item & D & Item & D \\
\hline 1 & .21 & 10 & .21 & 19 & .21 & 28 & .21 \\
2 & .20 & 11 & .20 & 20 & .20 & 29 & .20 \\
3 & .28 & 12 & .28 & 21 & .28 & 30 & 0,28 \\
4 & .15 & 13 & .15 & 22 & .15 & 31 & 0,15 \\
5 & .23 & 14 & .23 & 23 & .23 & 32 & 0,23
\end{tabular}




\begin{tabular}{llllllll}
6 & .35 & 15 & .35 & 24 & .35 & 33 & 0,35 \\
7 & .15 & 16 & .15 & 25 & .15 & 34 & 0,15 \\
8 & .31 & 17 & .31 & 26 & .31 & 35 & 0,31 \\
9 & .24 & 18 & .24 & 27 & .24 & 36 & 0,24 \\
\hline
\end{tabular}

Uji daya beda yang dilakukan terhadap skala orientasi karir ini menghasilkan 8 item yang dinyatakan memiliki daya beda yang baik. Hal ini didasarkan pada nilai Corrected item-Total Correlation pada uji daya beda menggunakan SPSS. Menurut Azwar (2007) suatu aitem dinyatakan memiliki daya beda yang baik jika nilai Corrected item-Total Correlation-nya 0,3 atau lebih 8 item dari 36 aitem tersebut memiliki daya beda yang baik karena memiliki nilai 0,3 , aitem tersebut diantaranya aitem no $6,8,15,17,24,26,33$ dan 35 .

Tabel 3

Uji daya beda Optimisme

\begin{tabular}{cccc}
\hline \multicolumn{4}{c}{ Nilai Daya Beda } \\
\hline Item & D & Item & D \\
\hline 1 & .25 & 7 & .31 \\
2 & .35 & 8 & .22 \\
3 & .39 & 9 & .42 \\
4 & .13 & 10 & .38 \\
5 & .39 & 11 & .25 \\
6 & .21 & 12 & .00 \\
\hline
\end{tabular}

Uji daya beda yang dilakukan terhadap skala orientasi karir ini meghasilkan 6 item yang dinyatakan memiliki daya beda yang baik. Hal ini didasarkan pada nilai Corrected itemTotal Correlation pada uji daya beda menggunakan SPSS. Menurut Azwar (2007) suatu aitem dinyatakan memiliki daya beda yang baik jika nilai Corrected item-Total Correlation-nya 0,3 atau lebih. 6 aitem dari 12 aitem tersebut memiliki daya beda yang baik karena memiliki nilai 0,3 , aitem tersebut diantaranya aitem no 2, 3, 5, 7, 9 dan 10.

\section{Uji reliabilitas}

Hasil penelitian ini pada variabel Orientasi Karir mendapatkan nilai koefisien sebesar 0,520 yang mengindikasikan bahwa hasil tersebut berada di posisi kurang dari 0,7 atau < 0,7. Dan pada variabel Optimisme kami mendapatkan nilai koefisien sebesar 0,682 yang mengindikasikan bahwa hasil tersebut berada di posisi kurang dari 0,7 atau $<0,7$. Jika dilihat kembali teorinya Azwar yang mgnindikasikan bahwa hasil nilai koefisien harus lebih besar dari 0,7 atau > 0,7 maka hasil uji reliabilitas pada variabel Orientasi Karir dan Optimisme berada di posisi kurang dari 0,7 atau > 0,7 artinya variabel belum dapat dikatakan reliabel.

\section{Uji Normalitas}

Gambaran orientasi karir pada mahasiswa keagamaan UIN SGD Bandung diperoleh dari perhitungan statistika deskriptif atau uji normalitas pada program SPSS dengan menggunakan total skor dari tiap subjek. Dari hasil perhitungan tersebut ditemukan bahwa 98 responden diperoleh skor orientasi karir terendah adalah 85 dan skor orientasi karir tertinggi adalah 112 dengan rata-rata 101,03 dan standar deviasi 6,123.

Tabel 4

Statistika Deskriptif Skor Orientasi Karir

\begin{tabular}{lllll}
\hline $\begin{array}{l}\text { Jumlah } \\
\text { Partisipan }\end{array}$ & $\begin{array}{l}\text { Skor } \\
\text { terendah }\end{array}$ & $\begin{array}{l}\text { Skor } \\
\text { tertinggi }\end{array}$ & $\begin{array}{l}\text { Rata- } \\
\text { rata }\end{array}$ & $\begin{array}{l}\text { Standar } \\
\text { deviasi }\end{array}$ \\
\hline 98 & 85 & 112 & 101.03 & 6.123 \\
\hline
\end{tabular}

Selanjutnya, gambaran optimisme pada mahasiswa keagamaan UIN SGD Bandung diperoleh dari perhitungan statistika deskriptif atau uji normalitas pada program SPSS dengan menggunakan total skor dari tiap subjek. Dari hasil perhitungan tersebut ditemukan bahwa 98 responden diperoleh skor orientasi karir terendah adalah 27 dan skor orientasi karir tertinggi adalah 44 dengan rata-rata 36,14 dan standar deviasi 3,689.

Tabel 5

Statistika Deskriptif Skor Optimisme

\begin{tabular}{lllll}
\hline $\begin{array}{l}\text { Jumlah } \\
\text { Partisipan }\end{array}$ & $\begin{array}{l}\text { Skor } \\
\text { terendah }\end{array}$ & $\begin{array}{l}\text { Skor } \\
\text { tertinggi }\end{array}$ & $\begin{array}{l}\text { Rata- } \\
\text { rata }\end{array}$ & $\begin{array}{l}\text { Standar } \\
\text { deviasi }\end{array}$ \\
\hline 98 & 27 & 44 & 36.14 & 3.689 \\
\hline
\end{tabular}


Dari hasil analisis deskriptif tersebut didapatkan nilai uji normalitas menggunakan Kolmogorov-Smirnov yang terdapat pada tabel berikut :

Tabel 6

Hasil Uji Normalitas

\begin{tabular}{ccc}
\hline Variabel & Signifikansi & Keterangan \\
\hline Orientasi & .063 & Normal \\
Karir & & \\
Optimisme & .44 & Normal \\
\hline
\end{tabular}

1. Uji Hipotesis (Pearson Correlation) Pada penelitian ini peneliti menggunakan analisis statistik uji hipotesis menggunakan software SPSS untuk mendapatkan nilai koefisien korelasi person (Person Product Moment Coefficient Of Correlation). Pearson dan hasil dari analisis tersebut dapat dilihat pada tabel :

Tabel 7

Korelasi antara Orientasi Karir dengan
Optimisme

\begin{tabular}{lccc}
\hline \multicolumn{1}{c}{ Variabel } & $\begin{array}{c}\text { Pearson } \\
\text { Correlation }\end{array}$ & Signifikansi \\
\hline Orientasi & Karir & .388 & .000 \\
$\&$ & & & \\
Optimisme & & \\
\hline
\end{tabular}

Pada kasus ini terlihat bahwa koefisian korelasi adalah 0,388 dengan signifikansi 0,000. Karena signifikansi $<0,05$, maka Ho di tolak, berarti $\mathrm{Ha}$ di terima. Artinya ada hubungan yang signifikansi antara Orientasi Karir dengan Optimisme Pada Mahasiswa Jurusan Keagamaan di UIN SGD Bandung.

Berdasarkan hasil koefisien korelasi diatas dapat terlihat bahwa adanya korelasi diantara dua konstruk tersebut. Dari data tersebut dapat disimpilkan bahwa semakin tinggi orientasi karir mahasiswa maka akan diikuti dengan semakin tingginya tingkat optimisme pada mahasiswa jurusan keagamaan Universitas Islam Negeri Sunan Gunung Djati Bandung dan itu berarti bahwa korelasinya bersifat positif.
Namun walaupun hasilnya berkorelasi positif harga koefisien korelasinya sebesar $0,388 \mathrm{Hal}$ tersebut menunjukkan bahwa korelasinya lemah.

\section{Diskusi}

Sejalan dengan kontemporer penelitian pada 30 tahun yang lalu tentang korelasi sifat dengan penciptaan tes orientasi kehidupan ukuran self-report dari optimisme dan telah direvisi pada tahun 1994 agar kontennya lebih fokus pada item agar lebih dekat pada harapan untuk masa depan seseorang inti konseptual dari sifat tersebut. Berhubungan tentang keyakinan atau self-efficacy dan harapan mahasiswa cenderung akan memilih karir nya sendiri berdasarkan pertimbangan keyakinan pada dirinya. Para mahasiswa tersebut yakin bahwa mereka akan bisa mengerjakan pekerjaan yang akan mereka dapatkan di masa depan. Mahasiswa tersebut yakin bahwa mereka mempunyai ilmu dan materi yang diberikan selama proses perkuliahan dapat menjadi bekal pencapaian karir mereka. Mahasiswa menetapkan banyak rencana untuk mereka di masa depan (Kurniawan, Priyatama, \& Karyanta, 2007).

Dari hasil tersebut ditunjukan bahwa mahasiswa yang memiliki self-efficacy career yang rendah mereka cenderung lebih memilih pekerjaan yang standar atau biasa saja karena salah satu alasannya adalah bahwasannya mereka telah memiliki pengalaman bekerja sebelumnya, serta mereka telah memikirkan untuk mendapatkan uang dan biaya untuk mengikuti pendidikan profesinya sendiri.

Berbicara tentang keyakinan (self-efficacy) dan harapan, mahasiswa memang memilih karirnya sendiri berdasarkan pertimbangan keyakinan diri. Mereka yakin mampu untuk mengerjakan setiap pekerjaan yang akan mereka dapatkan. Materi yang mereka dapatkan selama mereka belajar di universitas akan mereka jadikan sebagai bekal untuk karir mereka dimasa depan. Mahasiswa telah menetapkan banyak rencana untuk mereka dimasa depan. Self efficacy yang dialami mahasiswa dapat dikategorikan menjadi dua 
yaitu mahasiswa yang memiliki self efficacy career tinggi dan mahasiswa dengan self efficacy career rendah. Untuk mahasiswa dengan self efficacy career rendah yang cenderung memilih pekerjaan yang seadanya, mereka memilihnya dengan alasan bahwa mereka mereka cukup untuk menemukan sebuah pekerjaan tanpa harus ahli di bidangnya.

Sedangkan mahasiswa dengan self-efficacy career tinggi mereka sangat yakin dengan bekar serta kemampuan yang mereka miliki, dan akan mendapatkan karir yang mereka inginkan. Para mahasiswa tersebut akan semakil meningkatkan skill mereka dengan mengikuti beberapa kursus untuk menunjang karir mereka serta mencapai jabatan yang diinginkan. Selain self-efficacy, titik temu dari orientasi karir dan optimisme dapat dilihat pada hasil penelitian Kurniawan, Priyatama, \& Karyanta (2007) mengenai konsep diri yang memiliki hubungan signifikan dengan optimisme. Konsep diri merupakan salah satu faktor yang berpengaruh dalam terbentuknya suatu orientasi karir individu.

Pada mahasiswa yang memiliki konsep diri yang baik akan merasa yakin atas kemampuannya sehingga ia bisa meningkatkan skill-nya secara optimal serta lebih mengembangkan konsep diri yang ia bangun. Karena dengan mengembangkan konsep diri serta meningkatkan skill maka optimisme pada individu itu sendiri akan semakin tinggi (Kurniawan, Priyatama, \& Karyanta (2007).

Secara tidak langsung hal tersebut menunjukkan bahwa optimisme merupakan bagian yang sangat penting bagi seseorang dalam menjalani bagi seseorang dalam menjalani kehidupannya. Peterson \& Seligman (2004) juga berpendapat mengenai optimisme dan pesismisme. Menurutnya optimisme akan membuat orang menilai dengan sudut pandang yang lebih baik dan bersikap optimis, berbeda dengan optimisme, pesimisme lebih merujuk pada sudut pandang penilaian yang buruk dan menyebabkan orang menjadi pesimis serta takut untuk mencoba. Setelah melihat bagaimana pandangan Seligman mengenai sukses dalam karir disini kami sebagai penulis berpendapat bahwa cara pandang seseorang pada dirinya dipengaruhi oleh bagaimana ia menilai dirinya sebagai orang positif atau pesimis (Peterson \& Seligman, 2004).

Hanssen et al.(2015) juga menyarankan bahwa optimisme individu dapat menjadi komponen psikologis yang dapat mengembangkan ketahanan karir pada diri individu, karena individu yang optimis lebih memiliki kemampuan untuk bertahan dalam menghadapi kesulitan awal (Rasmussen et al., 2006) dan memiliki tingkat distres pikologis yang rendah.

Dalam Noordjannah (2002), orang yang memiliki sikap optimis dalam dirinya merupakan individu yang tidak pernah memandang permasalahan atau hambatan adalah hasil akhir dari segala upaya yang ia lakukan tetapi ia mencari titik terang dan jalan keluar dari masalahnya tersebut. Ia akan lebih sehat jika memiliki sifat optimisme yang tinggi sebab ia ingin menjadi orang yang berguna dan tidak komsumtif, dan juga mempunyai harapan tinggi serta positif. Jika ditinjau secara psikis orang yang mempunyai optimisme yang tinggi cenderung lebih cerdas dalam mengolah emosi seperti, memiliki daya juang yang tinggi, merasa mampu dalam melakukan sesuatu, serta tidak mudah depresi dan akan merespon segala sesuatu dengan positif sehingga menemukan jalan atas permasalahann yang dihadapi (Noordjanah, 2002).

Namun, rendahnya kekuatan korelasi antara orientasi karir dengan optimisme yang ditunjukkan oleh hasil uji korelasi spearman tersebut mungkin disebabkan oleh jumlah subjek yang terbilang tidak banyak, yaitu hanya 98 subjek, sehingga kekuatannya tidak begitu terlihat.

\section{Simpulan}

Peneitian ini menyatakan bahwa terdapat hubungan antara orientasi karir dan optimisme pada mahasiswa jurusan keagamaan di UIN SGD Bandung walaupun dalam level yang moderat. Sehingga hal ini mengasumsikan bahwa kedua variabel merupakan faktor penting 
di dalam proses pembelajaran yang ada di kampus maupun kehidupan sehari-hari.

\section{Saran}

Penelitian ini menjadi langkah awal untuk mengembangkan konstruk sabar dalam kehidupan. Penelitian selanjutnya seharusnya mampu mengkonstruksi skala sabar yang lebih komprehensif dengan menggunakan jumlah subjek yang lebih banyak dan menggunakan variasi metodologi yang lebih modern, sehingga bisa dianalisis tidak hanya secara klasik juga oleh program yang lebih canggih. Juga penggunaan skala pembanding atau kriteria variabel lainnya juga akan membantu meningkatkan properti psikometrik yang ada pada skala sebelumnya.

\section{Referensi}

Azwar, S. (2007). Metode Penelitian. Yogyakarta: Pustaka Pelajar.

Azwar, S. (2015). Validitas dan Reliabilitas. Yogyakarta: Pustaka Belajar.

Budiwati, T., Budiyono, A., Setyawati, W., Indrawati, A., Bidang, P., Ozon, P., \& Polusi, D. (2010). UNSUR-UNSUR KIMIA AIR HUJAN DI BANDUNG, 7(2), 100-112.

Emiriza, M. (2019). 5 prodi dengan peluang masuk tertinggi dan terendah di UIN Sunan Gunung Djati Bandung.

Fleeson, W., Jayawickreme, E., Jones, A. B. A. P., Brown, N. A., Serfass, D. G., Sherman, R. A., ... Matyjek-, M. (2017). Pemaparan metode penelitian kuantitatif. Journal of Personality and Social Psychology, 1(1), 1188-1197.

https://doi.org/10.1111/j.14697610.2010.02280.x

Hanssen, M. M., Vancleef, L. M. G., Vlaeyen, J. W. S., Hayes, A. F., Schouten, E. G. W., \& Peters, M. L. (2015). Optimism, Motivational Coping and Well-being: Evidence Supporting the Importance of Flexible Goal Adjustment. Journal of Happiness Studies, 16(6), 1525-1537. https://doi.org/10.1007/s10902-014-9572$\mathrm{X}$

Helmi Wibowo. (2013). ( Studi pada Jurusan Pendidikan Teknik Elektro FPTK UPI ).

IAIN Pekalongan. (2014). Prospek Kerja Prodi
Ilmu Al-Qur'an dan Tafsir. Pekalongan.

Kurniawan, S., Priyatama, A. N., \& Karyanta, N. A. (2007). Hubungan konsep diri dengan optimisme dalam menyelesaikan skripsi pada mahasiswa prodi psikologi fakultas kedokteran UNS. Psikologi, 275285.

Mujianto Solichin. (2017). Analisis daya beda soal. taraf kesukaran, butir tes, validitas butir tes, interpretasi hasil tes valliditas ramalan dalam evaluasi pendidikan. Journal Unipdu, 2, 192-213.

Noordjanah, A. (2002). HUBUNGAN HARGA DIRI DAN OPTIMISME DENGAN MOTIVASI BELAJAR PADA SISWA MAN MAGUWOHARJO SLEMAN YOGYAKARTA. Mycological Research, 106(11), 1323-1330.

Osipow, S. H. (1983). Theories Of Career Development (Third Edition). Englewood Cliffs, New Jersey: Prentice-Hall.Inc.

Peterson, C., \& Seligman, M. E. P. (2004). Character strengths and virtues: A handbook and classification. United States of America: American Psychological Association.

Prasetyo, G., \& Prasojo, L. D. (2016). Jurnal Prima Edukasia. Adobe, Developing At, Flash Integrative, $T H E$ Learning, Tematic On, Based Approach, Scientific of, Sub-Thems Beauty Heritage, Historical, 4, 54-66.

Purwanto. (2011). Evaluasi Hasil Belar. Yogyakarta: Pustaka Pelajar.

Ramdani, Z. (2018). Construction of academic integrity scale. International Journal of Research Studies in Psychology, 7(1), 8797. https://doi.org/10.5861/ijrsp.2018.3003

Rasmussen, H. N., Wrosch, C., Michael, F., \& Carver, C. S. (2006). Self-Regulation Processes and Health: The Importance of Optimism and Goal Adjustment, (December).

https://doi.org/10.1111/j.14676494.2006.00426.x

Riziq, F. (2015). Optimisme dan Efikasi Diri Pengambilan Keputusan Karir pada Mahasiswa Program Diploma III Kebidanan Optimism and Career Decision Self-Efficacy on Midwifery College Student PENDAHULUAN Survei Demografi Kesehatan Indonesia ( SDKI ) tahun 2012 menyebutkan ba, III, 137-152. 
Saefuddin Azwar. (2003). Sikap Manusia Terori dan Pengukurannya. Yogyakarta: Pustaka Pelajar.

Scheier, M. F., \& Carver, C. S. (1985). Optimism, coping, and health: assessment and implications of generalized outcome expectancies. Health Psychology: Official Journal of the Division of Health Psychology, American Psychological Association, 4(3), 219-247. https://doi.org/10.1037/0278-6133.4.3.219

Scheier, M. F., Carver, C. S., \& Bridges, M. (1994). Distinguishing optimism from neuroticism (and trait anxiety, selfmastery, and self-esteem): a reevaluation of the Life Orientation Test. Journal of Personality and Social Psychology, 67, 1063-1078.

Sharf, R. (1992). Applying career development theory to counseling. California: Cole Publishing Company.

Syaddad, A. (2016). Sarjana agama: Peluang dan tantangannya.

UIN Sunan Gunung Djati Bandung. (2019). Sejarah singkat UIN dan IAIN.

Ushfuriyah. (2000). Hubungan antara dukungan sosial dengan optimisme mahasiswa psikologi dalam menyelesaikan skripsi skripsi. Journal of Visual Languages \& Computing, 11(3), 287-301. 
HUBUNGAN ORIENTASI KARIR DENGAN OPTIMISME PADA MAHASISWA JURUSAN KEAGAMAAN UIN SUNAN GUNUNG DJATI BANDUNG 